\title{
Collapse dolines susceptibility mapping in Doukkala Abda (Western Morocco) by using GIS matrix method (GMM)
}

\author{
Othmane Boualla $^{1}$ (1) $\cdot$ Khalid Mehdi $^{1} \cdot$ Bendahou Zourarah $^{1}$
}

Received: 4 December 2015/Accepted: 8 December 2015/Published online: 23 December 2015

(C) Springer International Publishing Switzerland 2015

\begin{abstract}
The Doukkala-Abda region, rich in karst forms (caves, dolines, karren...) underwent in the recent years several collapse dolines, essentially due to the presence of caves or underground cavities. These collapse dolines are a risk, especially for densely populated areas, for man-made structures and for areas with agricultural interest. Thus, it's essential to draw susceptibility maps which are the first step for any hazard or risk assessment. Firstly, a collapse doline inventory was prepared by a geomorphological approach based on the visual interpretation of aerial photographs at medium scale combined with direct observations during field work. Secondly, a collapse dolines susceptibility map was prepared by a bivariate statistical method: GIS matrix method. Finally, this collapse dolines susceptibility map is validated by the degree of fit method.
\end{abstract}

Keywords Collapse doline susceptibility map .

Karstification - Geomorphological approach · GIS matrix method · Degree of fit method · Doukkala-Abda Morocco

Othmane Boualla

bouallaothmane@gmail.com

Khalid Mehdi

mehdi.k@ucd.ac.ma

Bendahou Zourarah

zourarah@gmail.com

1 Marine Geosciences and Soil Sciences Laboratory (LGMSS), Research Unit Associated CNRST 45, Department of Geology, Faculty of Sciences, Chouaïb Doukkali University, B.P.: 20, 24000 El Jadida, Morocco

\section{Introduction}

Dolines are natural enclosed depressions found in karst landscapes (Ford and Williams 1989; Field 2002). Dolines are also sometimes known as sinkholes, particularly by engineers and especially in North America (Williams 2006). Several classifications of dolines were proposed by numerous authors according to their form, their genetic processes, and their collapse velocities, etc. (Jennings 1985; Beck and Sinclair 1986; White 1988; Ford and Williams 1989; Waltham and Fookes 2003; Williams 2003). In this research, the classification of Ford and Williams (1989) is adopted. They distinguish the existence three types of dolines: solution, collapse and suffosion doline. These types of dolines occur in the study area but this paper focuses only on the collapse dolines.

In recent decades, the region of Doukkala Abda has experienced many of collapse dolines (Ferré and Ruhard 1975; Weisrock and Lunski 1987; Ouadia 1998). There were no victims, but the collapses affected the man-made structures (roads, railways, the electric lines of high or medium voltage, etc.) and the agricultural areas also (Fig. 1). For this reason, it is necessary to map these collapse dolines and their susceptibility.

The susceptibility of collapse dolines measures the spatial probability of its appearance at the surface, without any reference to a temporal frequency associated with the hazard (Galve et al. 2008, 2009; Nachbaur and Rohmer 2011). There are several methods to assess collapse dolines susceptibility which can be subdivided in two categories; qualitative and quantitative methods. Qualitative methods; such as geomorphological mapping (White 1988; GutiérrezSantolalla et al. 2005), heuristic method (Gao and Alexander 2003), deterministic method (Goodings and Abdulla 2002), are generally subjective and demand a good knowledge of all environmental, triggering factors on the basis of 

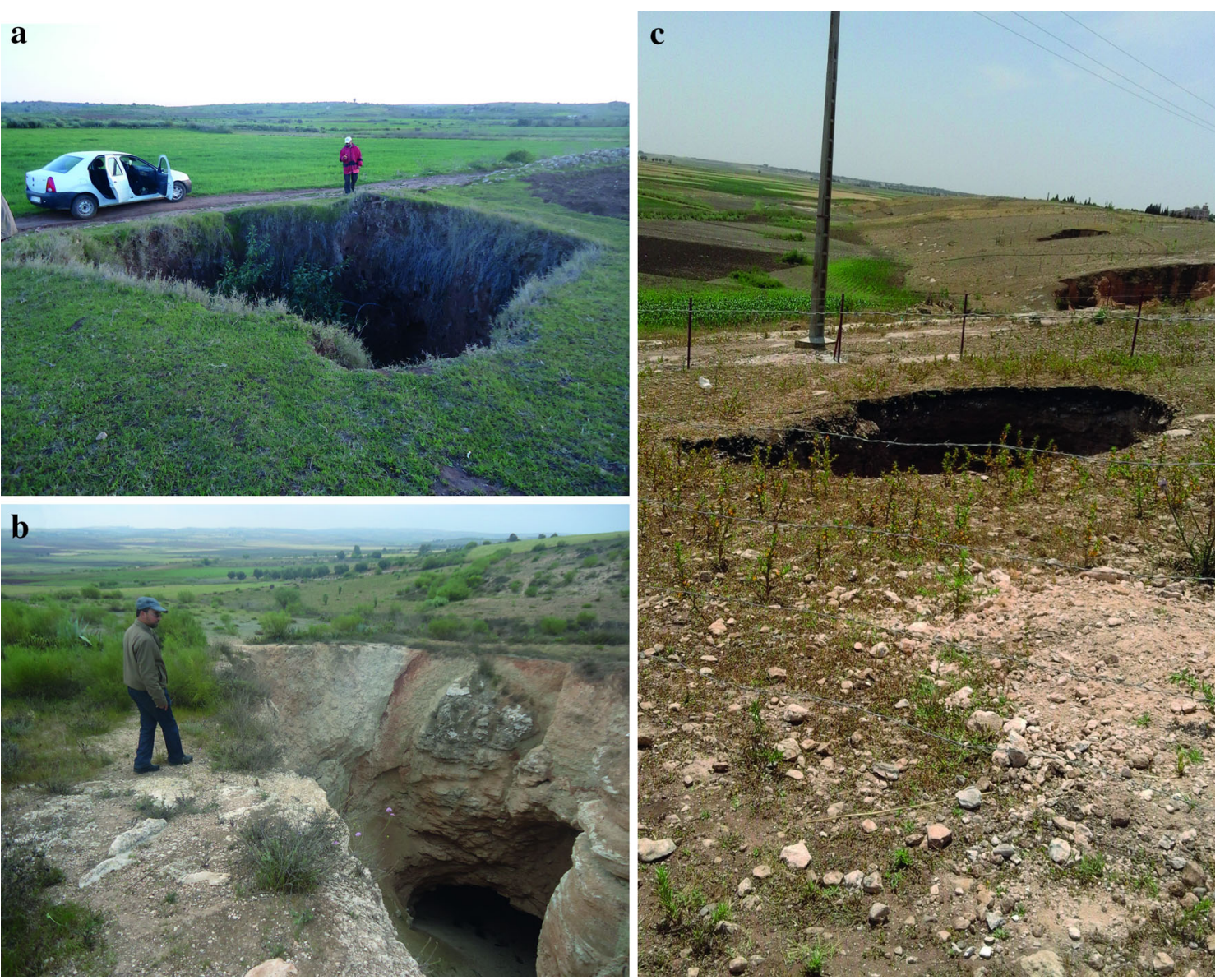

Fig. 1 Some of collapse dolines in the study area. a This collapse doline occurred in 1996 at the bottom of Oulad Sidi Allal Ben Jeddi polje. b This collapse doline shows the gypsum beds of Upper Jurassic, in the background of the photo you can see the precedent

investigator opinion (Guzzetti et al. 1999). However, quantitative methods are objective and produce numerical models of the occurrence of collapse dolines in any hazard area; such as statistical or probabilistic methods which are based on bivariate or multivariate analysis (Carrara et al. 1995; Yilmaz 2007; Galve et al. 2008, 2009; Lamelas et al. 2008; Oh and Lee 2010; Papadopoulou-Vrynioti et al. 2013).

In this research, a statistical method, known as the GIS matrix method (GMM), is adopted as it is widely used by the scientific community to assess landslides susceptibility (DeGraff and Romesburg 1980; Maharaj 1993; Cross 1998; Irigaray 1995; Irigaray et al. 1999, 2007; Clerici et al. 2002; Jiménez-Perálvarez et al. 2009). This is a bivariate statistical analysis that is based on indirect mapping where the conditioning factors are entered into a GIS and crossed with a collapse dolines inventory.

Furthermore, any susceptibility model or map must be validated by two methods (Guzzetti et al. 2006); i.e., the validation of a collapse doline susceptibility model can be ascertained using the same collapse doline data used to obtain the susceptibility assessment (Edmonds 2001; polje. c Collapse doline occurred in January 2015 near an electricity pylon, also note the other collapse dolines in the background of the photo (locality of Moul El Bergui)

Kaufmann and Quinif 2002; Yilmaz 2007; Dai et al. 2008), or by using independent collapse dolines information (Galve et al. 2008; Lamelas et al. 2008) not available to build the model of collapse dolines susceptibility map. In the anterior works which were carried out in the study area (Mazéas 1967; Theilen-Willige et al. 2014), the dolines susceptibility models were generated but not tested.

Consequently, the objectives of this paper are: (1) to realize a collapse doline inventory based on aerial photographs and direct observations in the field, (2) to identify the environmental factors by field survey, (3) to build the collapse doline susceptibility map by GIS matrix method, and (4) to validate the collapse doline susceptibility map by using the method known as degree of fit.

\section{Study area}

The study area is part of Doukkala Abda region, in western of Morocco. From a structural viewpoint, it belongs to mesetien area which is characterized by the presence of a 
Meso-Cenozoic tabular coverage based on a primary substratum which is folded and leveled (Roch 1950). Its boundaries run from Oualidia and Zemamra North to South Swiria Laqdima (the Tensift river mouth) and Jemaat Shaim east to Cap El Beddouza west (Fig. 2).

\section{The karstification factors}

The study area is affected by a high degree of karstification (Gigout 1951; Ferré and Ruhard 1975; Ouadia 1998). This karstification is favored by a set of factors such as the climate, the lithology of the rocks, the tectonics, the geomorphology, and the hydrogeology (Ouadia 1998).

\section{Climate}

The climate is of Mediterranean type belonging to the semi-arid zone (Ferré and Ruhard 1975; Carruesco 1989). It is characterized by a concentrated rainfall in autumn and winter, and a long dry period during Spring and Summer. Due to the proximity of the study area to the Atlantic
Ocean, the temperatures are moderate on the coast and are raised to inland areas (Ouadia 1998). In Safi city, the average annual temperature is $19.0^{\circ} \mathrm{C}$ and the average annual rainfall is $350 \mathrm{~mm}$ (climate-data.org). This proximity of the study area to the Atlantic Ocean, improves the karstic process (Ouadia 1998). However, most of the recent karstic developments occur during the wetter periods, for example Upper Pleistocene (Weisrock and Lunski 1987).

\section{Lithology}

Most of the outcrop rocks are favorable to karstification (Roch 1930; Gigout 1951; Choubert 1956, 1957). In fact, they are calcareous rocks in the whole of the study area and gypsiferous rocks in the east and southeastern of the study area (cf. Figs. 2, 3). According to Ferré and Ruhard (1975) geological levels susceptible to intense karstification in this region are: (1) the Upper Jurassic-age limestone and gypsum in Abda, (2) the Hauteriviens-age Dridrat limestone (Dridrat is a zone in the north of Safi rich in limestone), (3) the lower and middle Cretaceous-age gypsiferous marl in

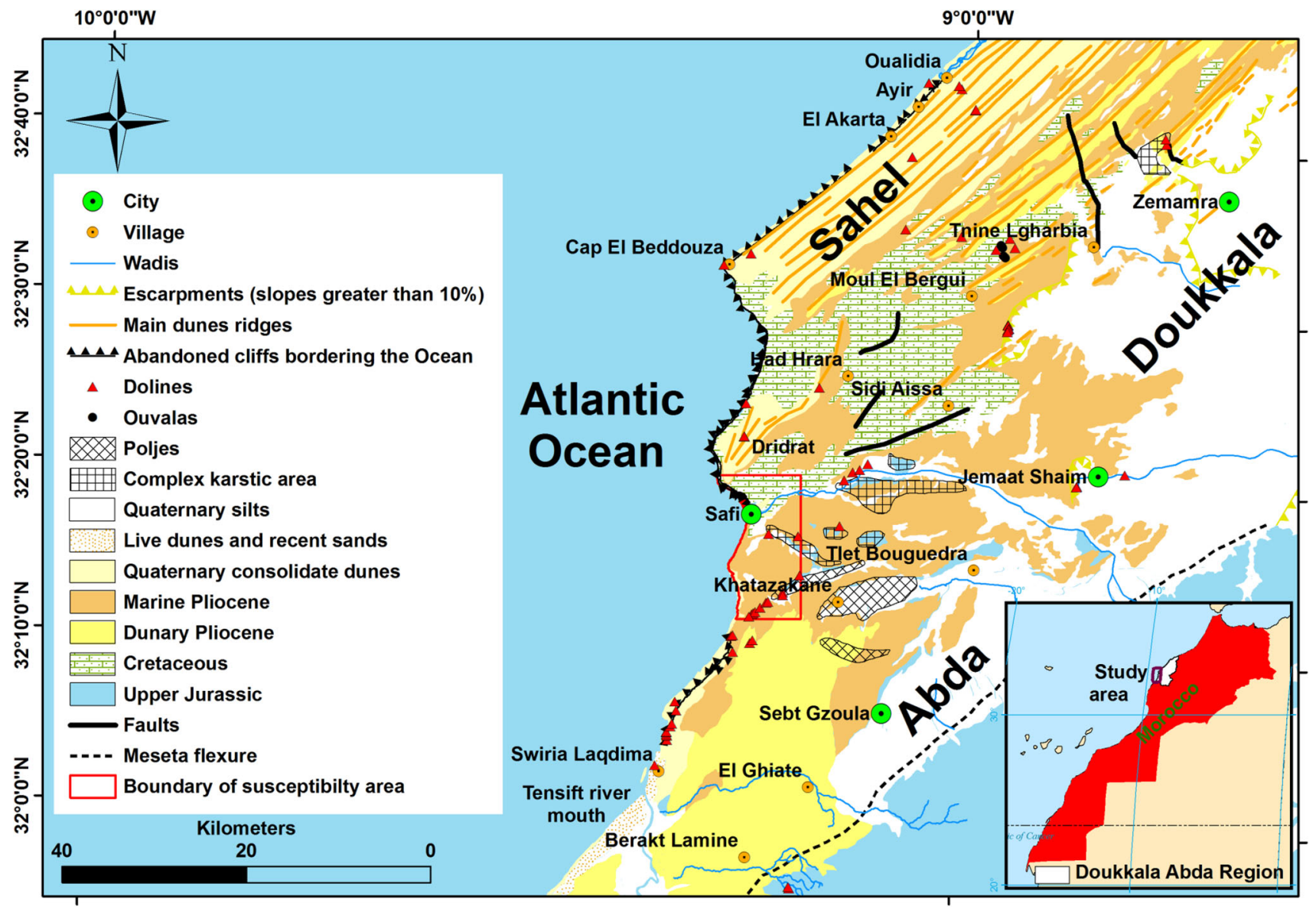

Fig. 2 Location of the study area on the geomorphological map (Ferre and Ruhard 1975, modified). The red rectangle delimits the area where the susceptibility analysis was conducted 


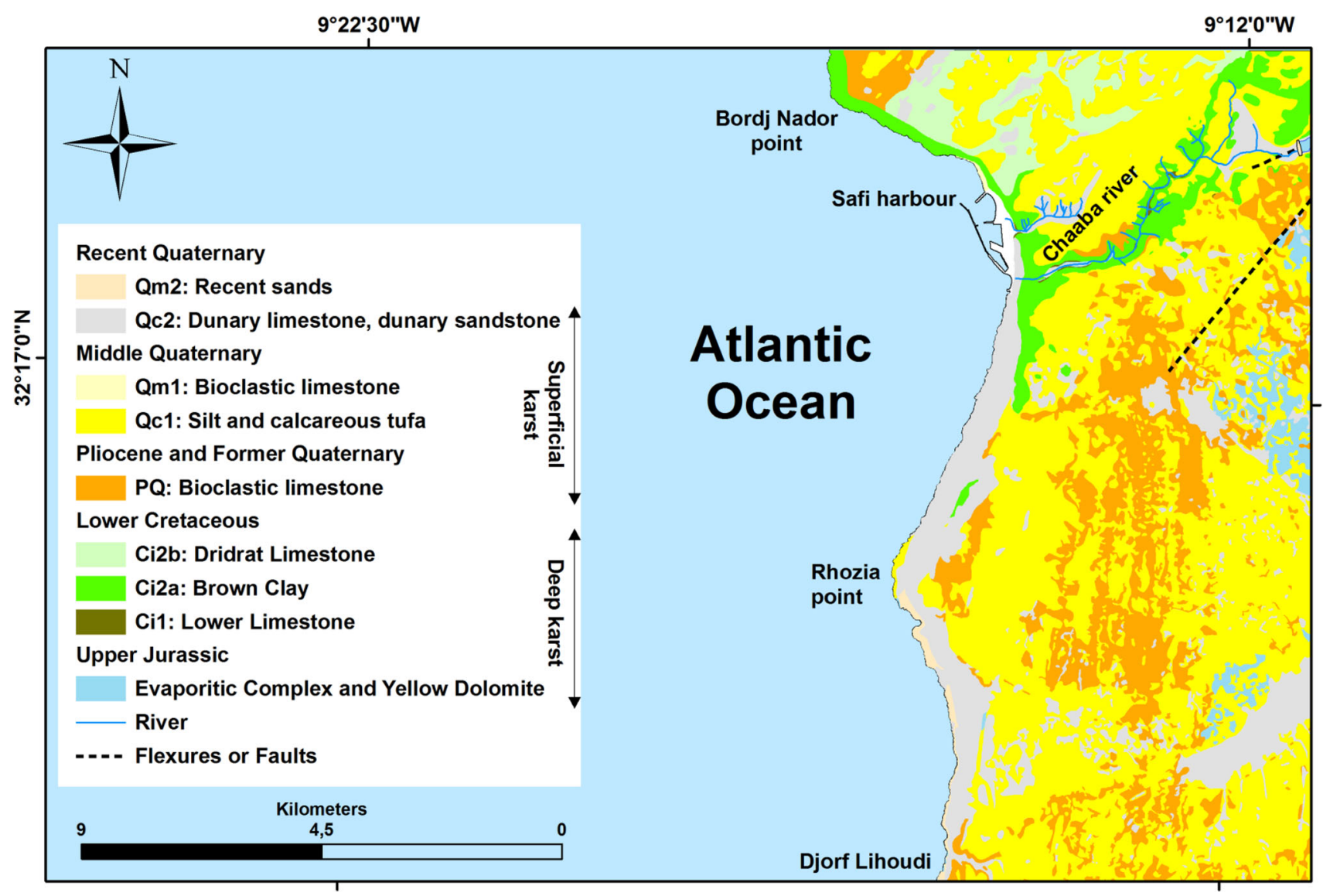

Fig. 3 Simplified geological map of the susceptibility study area (Mazéas 1967, modified)

Doukkala, (4) the Cenomanian-age limestone in Doukkala, (5) the Plio-Quaternary-age clastic limestone in Doukkala Abda.

The formations of Jurassic and Cretaceous form the deep karst while the Plio-Quaternary formations constitute the superficial karst. The two karsts are superimposed and they intercommunicate (Weisrock and Lunski 1987).

\section{Tectonics}

According to Ferré and Ruhard (1975), tectonic is essentially the tertiary age, therefore both Rif and Atlasic orogenic movements gave structure to the region of DoukkalaAbda. The folds and the faults take two main directions: a NS direction, often superimposed Hercynian tectonic elements, and a direction SW-NE to EW, which is that of the Atlas orogeny (Alpine). All this is soft tectonics: indeed, folds have a large radius of curvature and flexures at the low dip angle; faults are rare and concern only very limited areas. (cf. Fig. 3).

The Tectonic guides and controls the orientation of the karst forms (El Gharbaoui 1987). Indeed, most closed depressions (dolines, uvalas and poljes) have a structural origin (Ferré and Ruhard 1975) and are aligned along the major accidents according to three main directions: N170-N195, N040-N070 and N080-N115 (Weisrock and Lunski 1987). The first direction has a Hercynian age orogeny and the two last directions have an Atlas (Alpine) age orogeny.

The neotectonics were enhanced karstification by facilitating the underground drainage of the Doukkala Abda plain according to a fault system, affecting the plain by subsidence and finally by uplifting the Western Sahel (Ouadia 1998).

\section{Topography}

The analysis of the geomorphological map (Fig. 2) of the study area (Ferré and Ruhard 1975) shows two distinct zones: the hinterland and the coastal zone. Going from east to west, the first zone is Doukkala Abda plains that contain the crypto karsts and valleys. The second zone is the Sahel which is constituted by consolidated dunes of the PlioQuaternary age. This geomorphological unit is rich by numerous karst landforms such as karren, poljes, uvulas, sinkholes (dolines), and caves (Fig. 4). 

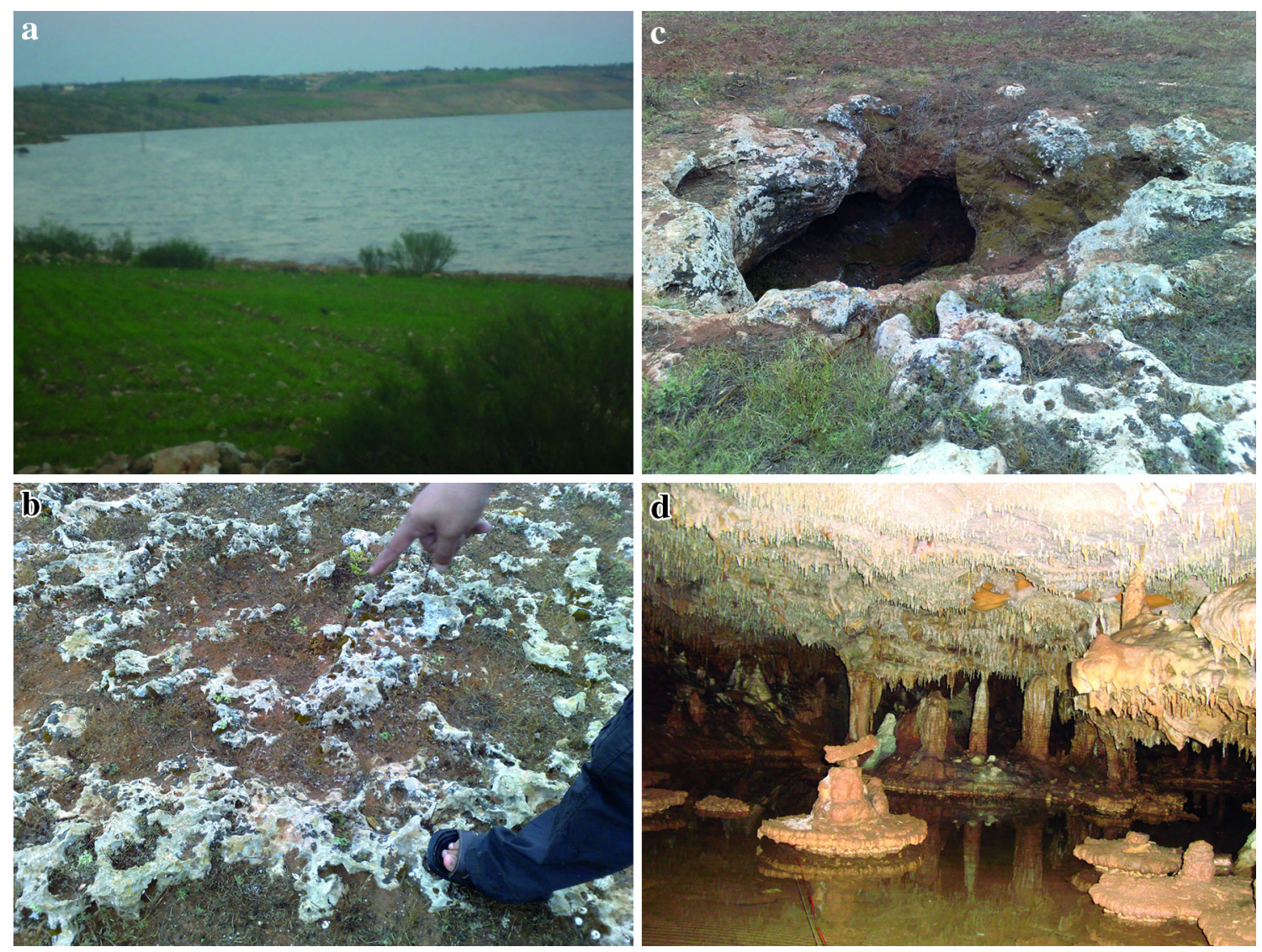

Fig. 4 Numerous karst landforms such as poljes (a), karren (b) and caves; Goraan cave near Cap El Beddouza (c) and (d)

There are three main poljes; two near Khatazakan and one near Sebt Gzoula (Cf. Fig. 2). These poljes have a NESW to E-W direction that confirms their structural origin. The geomorphological map shows also several complex karstic areas which are the place of numerous types of dolines. These dolines are aligned or dispersed (Ferré and Ruhard 1975).

\section{Hydrology and hydrogeology}

Due to its low slope, its endorheic appearance and the presence of natural barriers formed by the Sahel consolidated dunes, the poor drainage of surface water in the plain of Abda Doukkala has favored the emergence of a set of underground outlets that worked during the quaternary rainy periods and sometimes still work now (Ferré and Ruhard 1975; Ouadia 1998). These underground outlets aliment the aquifers of the region.

There are three major aquifers; firstly, the Plio-Quaternary Formation along of the Atlantic coastal area. It is formed by the bioclastic and dunary limestones. This formation is porous and much fissured (cf. Fig. 4c, d) with laminar and karstic flows (Hazan and Monition 1963). Secondly, the Dridrat Limestone Formation, which is localized in the North of Safi. It is a karstic formation with a very significant cracking where real caves can develop. Finally, the Upper Jurassic (Evaporitic Complex Formation) in the east and southeast study area. It is formed by thick layers of limestone and gypsum alternating with marl beds and has a permeability of cracks: water circulations are often made by real galleries resulting from the dissolution of limestone and gypsum. This intense karstic dissolution improves the dolines processes. (Ferré and Ruhard 1975).

\section{Collapse dolines processes: predisposing, triggering and aggravating factors}

Collapse refers to rapid downward movement of the ground which is mainly formed by mechanical processes, but in all cases the collapse has to be preceded by dissolution of the karst rock to form a void into which material can fall (Williams 2006). Various predisposing, triggering and aggravating factors (of natural or human origin) interact to these collapse processes.

The lithology is the principal predisposing factor to collapse. In fact, dolines are especially common in terrains underlain by carbonate rocks, and are widespread on 
Fig. 5 The observed lithology inside collapse dolines

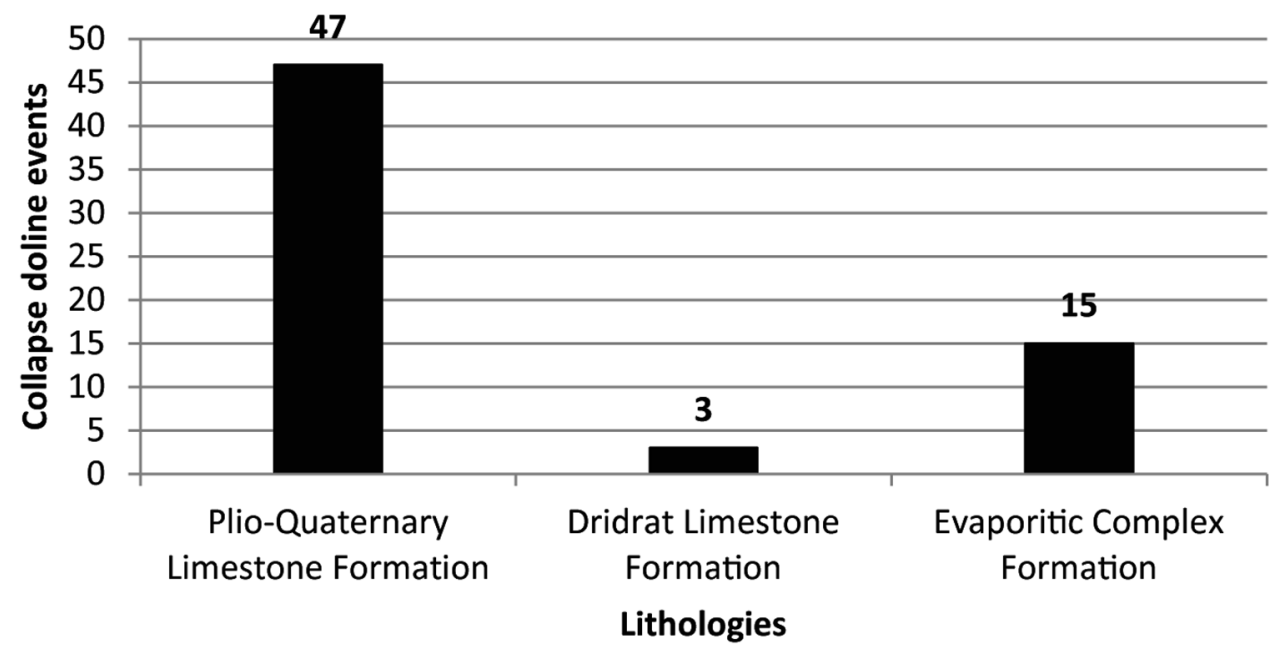

Fig. 6 The volume of natural underground cavities observed in the South and the North of the city of Safi

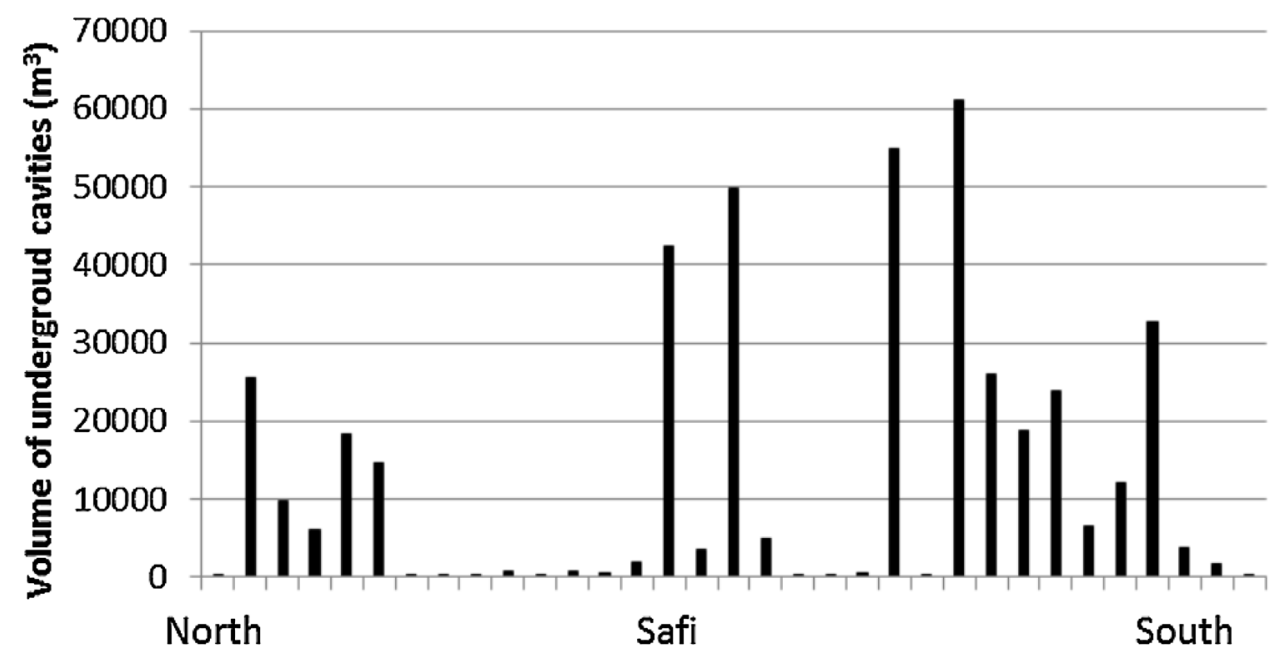

Collapse dolines in the North and the South of Safi evaporite rocks (Williams 2006). In the studied area, the observed lithology inside collapse dolines is either limestone or gypsum, or both (Fig. 5). These two lithologies are susceptible to excavation in relation to karstification. In fact, the dissolution processes mainly affect the deep karst. Therefore, the natural underground cavities develop with the time by the mechanical processes; the roof of these underground cavities stopes upward through the superficial karst, ultimately causing it to collapse. The presence of these underground cavities into the Upper Jurassic Formation was attested by coring in the south of the study area (Weisrock and Lunski 1987).

In addition, the volume of natural underground cavities observed in the south of the city of Safi are very large in comparison with the ones in the North (Fig. 6) and this is due to the presence of gypsum and anhydrite layers in the Upper Jurassic Formation that outcrop at the surface in the South and are highly susceptible to karst dissolution processes. According Nicod (1976), the specific dissolution of gypsum and anhydrite is estimated at 10,000 t/ $\mathrm{Km}^{2} /$ year, from 2 to 3 years are sufficient to form a cave, and from 6 to 8 years to collapse its roof.

The Tectonic is another predisposing factor and it guides the collapse doline alineaments. In other words, the collapse dolines take $\mathrm{N}-\mathrm{S}$ or $\mathrm{NE}-\mathrm{SW}$ directions that perfectly coincide to the directions of faults and joints (Ouadia 1998). This is the case for example of two collapse dolines in Douar Sidi Brahim Mhamed $10 \mathrm{~km}$ northwest of Khemis Zemamra. These two collapses are connected by a joint with a length of $1.5 \mathrm{~km}$ and $\mathrm{N}-\mathrm{S}$ direction. This direction has been observed in other cases of collapse dolines such as Oualidia (alignment of a collapse dolines with three burial dolines), Moul El Bergui (alignment of seven collapse dolines), from Jorf Lihoudi to Khatazakan (alignment of a dozen collapse dolines) and Jemaat Shaim (alignment of three collapse dolines) (Fig. 7). 

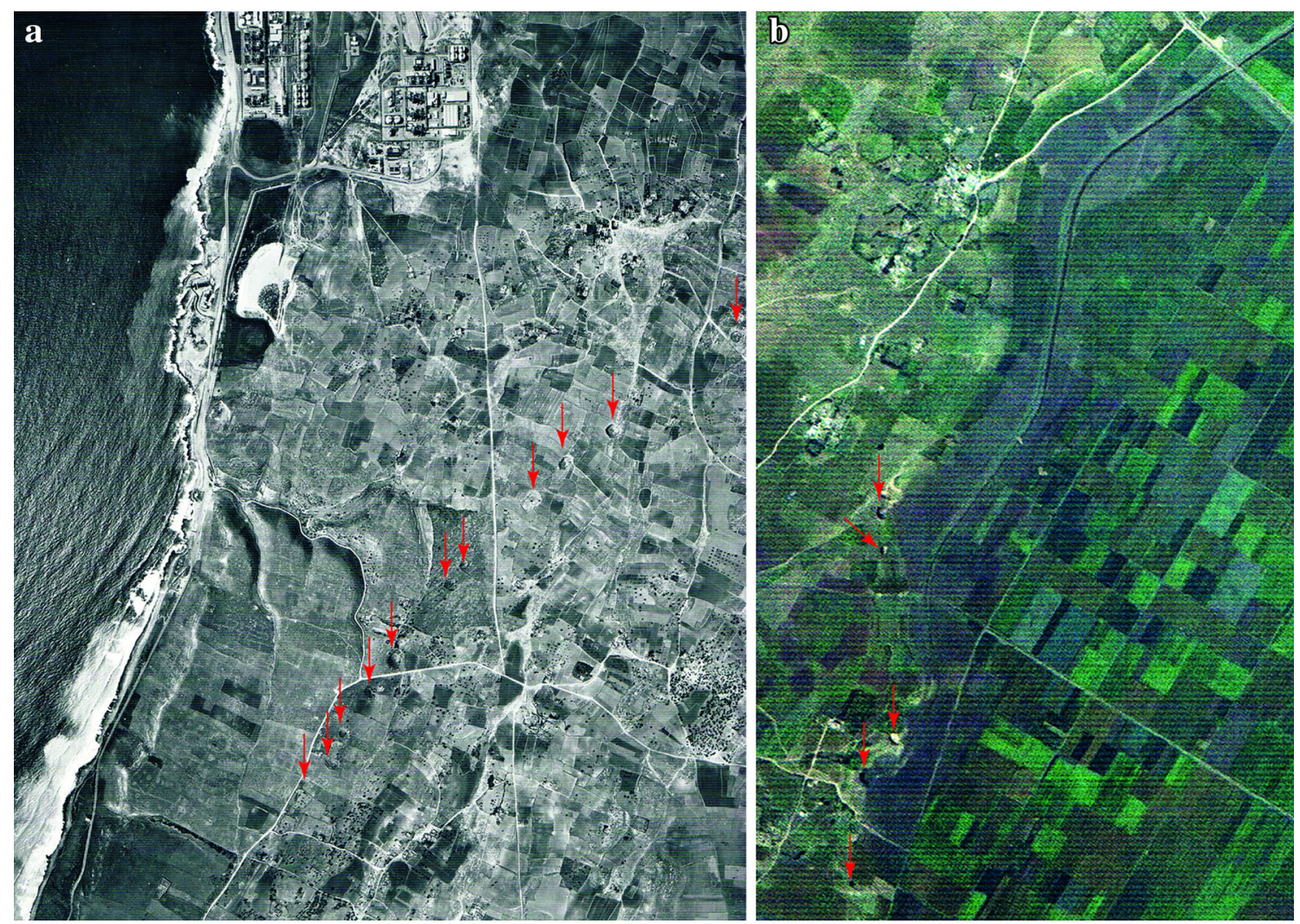

Fig. 7 Collapse doline alineaments observed in the aerial photos. a Alignment of a dozen collapse dolines from Jorf Lihoudi to Khatazakan (1/ 17,500 in scale, 1983). b Alignment of five collapse dolines in the Moul El Bergui area $(1 / 20,000$ in scale, 2010)

The topography is an important conditioning factor to collapse dolines and their alineaments. In fact, it appears that collapse alignments correspond to the SSW-NNE direction consolidated dunes ridges of Sahel which are described by Aboumaria (1993). In addition, they are located either in the inter dune depressions and karst depressions such as poljes, or they are located at the boundary between the Doukkala Abda plain and the Sahel.

At these limits, many underground outfalls (sinks) were identified near to these collapse dolines. Thus, during heavy rainfall, the flood waters and the drainage pattern of the plain are drained by these underground outfalls, which reactivate the karst network (Gilli 2011). This reactivation leads to the emergence of new collapses near to these drainage points.

Among the triggering factors of the collapse dolines: the heavy rainfall (Ferré and Ruhard 1975; Ouadia 1998), or the earthquakes or the human activities such as agriculture (Papadopoulou-Vrynioti et al. 2013).

Aggravating factors of human origin have also been identified. They are the result of the discharge of sewage directly at the sinks or the old collapse dolines. This is the case, for example, for the city of Jemaat Shaim that the wastewater is discharged to a swallow hole called "Ayn
Quarquar" $1 \mathrm{~km}$ west of the city where signs of recent collapses have been detected (Fig. 8a).

Another aggravating factor was observed in relation with agricultural activities (Fig. 8b). It is said that the drainage of surplus irrigation water of the lower service is injected directly into the underground network karst. Indeed, a collecting channel of this water plunges directly into a collapse doline called "Haroun" in the rural town of Moul El Bergui (36 km to the north of Safi). The original purpose of the injection of excess irrigation water, which began in the early eighties, was the artificial recharge of groundwater karst, but it has unfortunately reactivated underground karst network facilitating soil erosion, expanding underground cavities and leading to recent collapses observed close to this underground outlet.

\section{Materials and methods}

Diverse materials and methods were used to collect data of collapse dolines such as aerial photos, Google Earth imagery, topographic and geological maps, and field works. All data were used to build an inventory map of collapse dolines and a susceptibility map. 

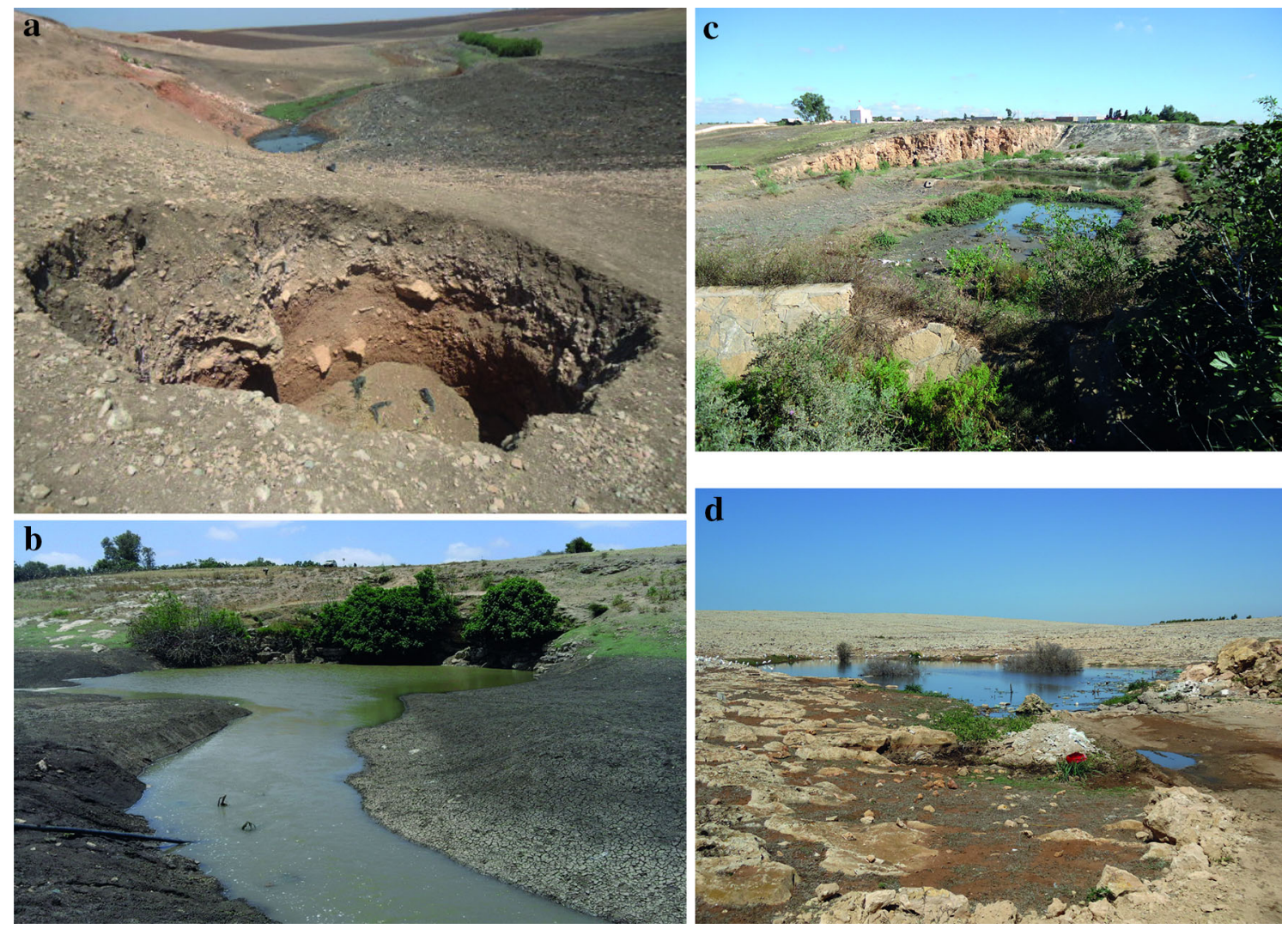

Fig. 8 Aggravating factors observed in the study area (a) a collapse doline detected near a swallow hole where the wastewaters of Jemaat Shaim city are discharged (b) the drainage of surplus irrigation water by injecting directly into a collapse doline near of the Moul El Bergui

\section{Collapse dolines inventory data}

In this paper, the principal methods used for the acquisition of collapse dolines information are geomorphological field mapping and visual interpretation of aerial photographs. Other methods were used to complete the inventory such as the speleological explorations, the visual interpretation of Google Earth Imagery, the analysis of topographical and geological maps, and the interviewing of the local people.

\section{Geomorphological field mapping with speleological explorations}

This method, normally used to map the landslides, consists of a mapping collapse dolines in the field (Brunsden 1985; Guzzetti et al. 2012). In addition, this method was combined by speleological explorations of the karst areas where collapse dolines occurred; by using the adequate speleological material, several collapse dolines were explored inside. These collapse dolines were identified, photographed, described and pointed by GPS; they were mapped as points in this first step. The classification of town (c) the discharge of sewage directly at the underground karst network in the Khemis Zemamra city (d) the discharge of sewage into a doline near of the Oualidia town

dolines adopted in this study is that of Ford and Williams (1989). Data collection in the field was made using technical sheets. Such records were made in Excel for all types of the identified dolines; all of these fact sheets are an updated database. This database has been reinforced by interviewing of local people especially for the small collapse dolines. Finally, field work is also conducted to check (validate) inventory map prepared using other techniques, chiefly the interpretation of aerial photographs (Brunsden 1985; Guzzetti et al. 2000, 2012).

\section{Visual interpretation of aerial photographs}

In this paper, a set of 18 panchromatic vertical aerial photographs at medium scale was used, and this covered a part of the study area (see the red rectangle in Fig. 2). These aerial photographs were taken in 1983 at 17.500 scales, in 2006 at 30.000 scales and in 2010 at 20.000 scales. For the interpretation, a stereoscopic vision was used to define the shape of dolines. In addition, a visual interpretation of Google Earth imagery was carried out to make the inventory as exhaustive as possible. After this 
operation, the boundary of these collapse dolines was digitalized, with ArcGIS 9.3 software (Editing tool), as polygons in this second step.

\section{Predisposing factors}

In this research, several predisposing factors are selected such as the topography (DEM and its derivatives: elevation, slope gradient, aspect) and geology (lithology).

The most important determinant factor is the digital elevation model (DEM). This DEM is generated by the digitalization of height spots and contour maps at 20.000 scale and 5-10 m contour intervals (Mazéas 1967). With ArcGIS 9.3 (ESRI) software, Topo to raster tool (TOPOGRID) was used to generate a raster DEM at $5 \mathrm{~m}$ resolution. According to Reuter and Nelson (2009), the TOPOGRID method should be applied in preference to any other interpolation approach available in ESRI products for creating a DEM. Then numerous derivate maps can be produced from this DEM using objectively simple GIS processes (spatial analyst tools: surface tool; hydrology tool; etc.). In this research, two types of the topographical predisposing factors derived from the DEM were used for collapse dolines susceptibility assessment and mapping: slope gradient and slope aspect. These two causal factors are the most used in research works at the international scale for the dolines susceptibility assessment (Galve et al. 2008, 2009; Papadopoulou-Vrynioti et al. 2013).
Geology (lithology) is another predisposing factor which is prepared from a set of geological maps at 1:200.000 (Roch 1930; Gigout 1954a, b; Choubert 1956, 1957) and geotechnical map of Safi at 1:20.000 (Mazéas 1967) for a study area. Nine lithological formations were digitized with ArcGIS software as polygon features, and then they were reclassified where each class was associated with an integer.

\section{Collapse dolines susceptibility assessment and mapping}

\section{Method of analysis: the GIS matrix method (GMM)}

The GMM was successfully applied to different geological settings and countries (Jiménez-Perálvarez et al. 2009). The collapse dolines susceptibility can be assessed by delineating terrain units differently predisposed to collapses. It is based on the computation of three matrices: total surface of the study area matrix (TSM), collapse dolines matrix (CDM), and susceptibility matrix (SM).

First, the TSM matrix (Fig. 9, Step: 1) was calculated by making all the possible combinations among the classes of predisposing factors selected, and then calculating the area occupied by each combination. Three derivative maps (slope angle, elevation, and slope aspect) were produced from DEM of study area "DEM_SAFI" using the ArcGIS spatial analyst tools "Slope", "Reclassify" and "Aspect"

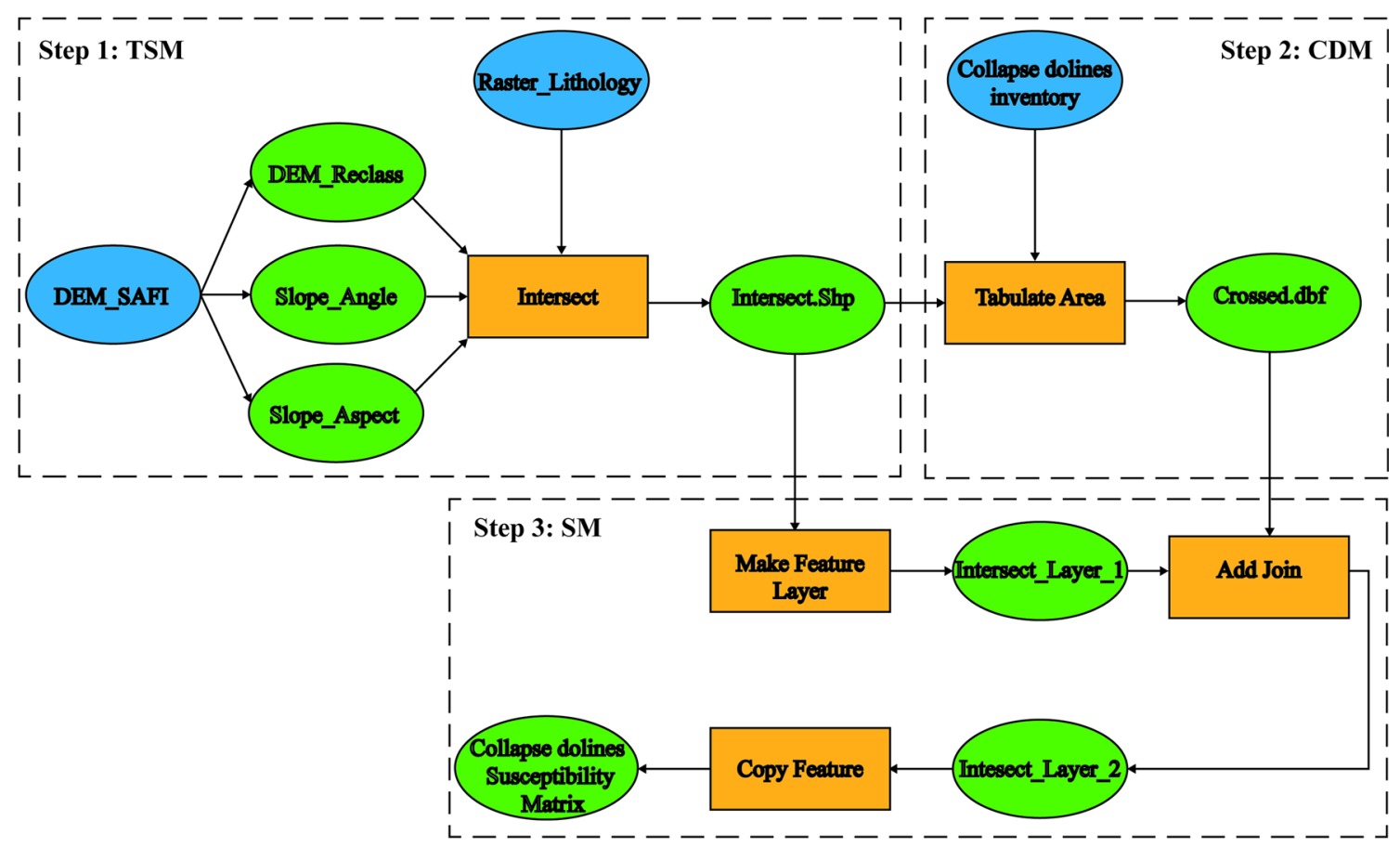

Fig. 9 Flow chart shows the adopted model to build the collapse doline susceptibility map, step 1 total surface of the study area matrix (TSM), step 2 collapse dolines matrix (CDM), step 3 susceptibility matrix (SM) 
respectively. The elevation was reclassified into ten new values. Then slope angle and slope aspect were also reclassified into five new values using "natural breaks" method. The three layers were transformed into a vectorial format "shp" to analyze with various attribute tables of each predisposing factor map. This transformation was made by "Raster to Polygon" tool and which conserves the same values of each pixel from raster format to vectorial format, and there is no loss of any information. Then the three vectorial formats were homogenized to have in the attribute table a number of files equal to the number of map classes; this operation was carried out by "Dissolve" tool. The three dissolved layers were then crossed with the fourth predisposing factor, lithology layer: "Rastert_lithology", by using "Intersect" tool. This intersection permits making all possible combinations between all classes of predisposing factors previously designated. A new field "value" was added to the TSM generated layer "Intersect.shp". Then, the value of this field is a simple identifier which was created by a simple calculation expression "[FID]" using "Calculate Field" tool. This field value will be used in the next step for more calculations.
A CDM (Fig. 9, Step: 2) was realized by calculating areas affected by the collapse dolines in each combination of classes of the selected predisposing factors. The collapse dolines inventory is a vectorial layer and it was reclassified in two values: " 1 " for the absence of collapse dolines and "2" for their presence. The CDM was calculated by crossing the reclassified collapse dolines inventory with the TSM by using "Tabulate Area" tool. The results were presented in table "Crossed.dbf", with three fields: "value", previously added from the TSM and corresponding to the identifier of each combination of classes of the predisposing factors selected, "value_2" with the area affected by the collapse dolines in each combination, and "value_1" with the area not affected in each combination. The sum of the two values represents the total area of the study area.

Finally, in the SM, each cell shows a value calculated by dividing the value of the cell in the CDM by the value of the cell in the TSM (Fig. 9, Step: 3). The cell values in the SM represent an assessment of relative susceptibility corresponding to each combination of predisposing factors in the cell. Each SM value shows the percentage of collapse

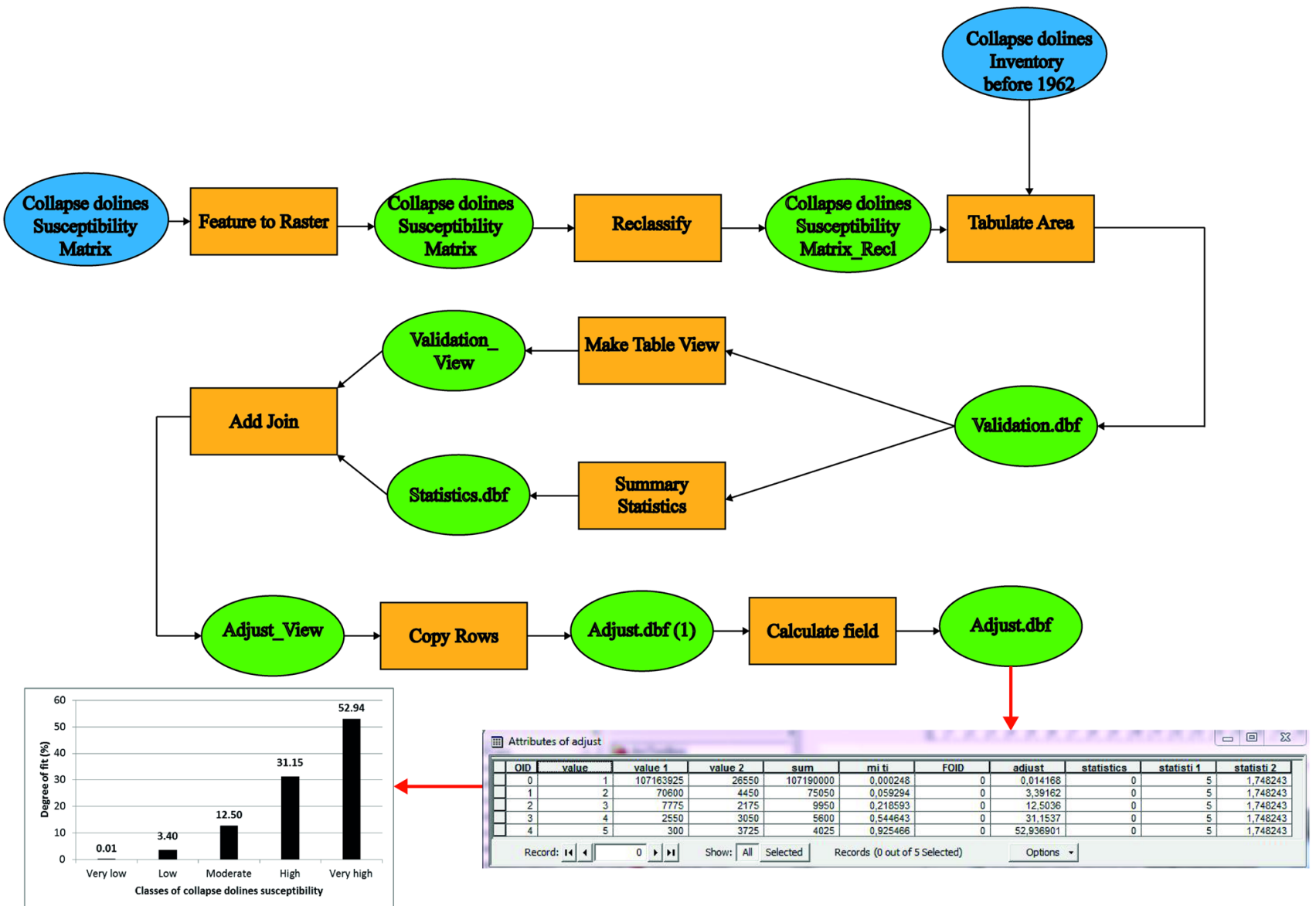

Fig. 10 Flow chart of the validation model methodology, the column "adjust" is transformed to a graph 
dolines in each combination of predisposing factors in regard to the total area occupied by the respective combination of predisposing factors. These computations were carried out by means "Add Field" and "Calculate field" tools. Firstly, a new field "Total_value" was added and calculated by using the expression "[value_1] $+[-$ value_2]". After, a second field "Percent" was also added and calculated by using the calculation expression " $\frac{\text { value_2] } \times 100 \text { " }}{\text { Total_value }]}$. Then, by using "Make Feature Layer" tool, a feature layer was created and joined to a table view "Crossed.dbf" by using "Add Join" tool. The "Add Attribute Index" tool was used to increase performance of the join which, in the ArcGIS geoprocessing, is temporary as a layer and will not persist from one session to the next unless it is saved. Thus, the obtained layer was saved to a feature class by means "Copy Features" tool. The result of this last step is "Susceptibility_matrix.shp" with an attribute table composed by a set of fields where "Crossed_pe" represents the value of susceptibility.

\section{Validation of the collapse dolines susceptibility maps}

In this paper, two collapse dolines inventories at different periods are used. The oldest one (sixteen collapse dolines occurred before 1962) is used to produce the collapse dolines susceptibility map that is then combined with the recent collapse dolines inventory map (four collapse dolines generated after 1962) for validating our map. The method adopted uses the degree of fit to assess the association between the inventory and the collapse dolinessusceptibility map. The quality of the map was assessed by techniques of spatial autocorrelation and measuring the degree of fit between a given set of data and the map (Goodchild 1986; Jiménez-Perálvarez et al. 2009).

The degree of fit $\left(D F_{i}\right)$, as applied to collapse dolines map, is defined as follows:

$D F_{i}=\frac{m_{i} / t_{i}}{\sum m_{i} / t_{i}}$

where $\mathrm{m}_{i}$ is the area occupied by the collapse dolines areas at each susceptibility level $i$, and $\mathrm{t}_{i}$ is the total area covered by that susceptibility level. The degree of fit for each susceptibility level represents the percentage of affected area located in each susceptibility class. The lower the degree of fit in the low and very low susceptibility classes (relative error), and the higher the degree of fit in the high or very high susceptibility classes (relative accuracy), the higher the quality of the susceptibility map will be (Fernández et al. 2003; Irigaray et al. 2007).

For the building of the validation process a model was adopted (Jiménez-Perálvarez et al. 2009) in this study by using ArcGIS geoprocessing (Fig. 10). Firstly, a new field "value" was added to the SM and calculated by using the expression "Int ([Crossed_pe])", then the SM was transformed into raster format by using "Feature to Raster" tool and reclassified in the set of susceptibility classes previously selected: very low, low, moderate, high and very high. This reclassified map was crossed with the collapse dolines inventory by using "Tabulate Area" tool. The collapse dolines inventory used in this validation process is different from that previously used in susceptibility model. Afterward, the cross tabulation was built; new fields were added and calculated with values of: $m_{i}, t_{i}, m_{i} / t_{i}$, etc. The operation $\left(\sum m_{i} / t_{i}\right)$ was calculated by "Summary Statistics" tool, which may later be added by "Add Join" tool to the required calculations and finally a table "adjust.dbf" was obtained with one of its columns representing the values of degree of fit for each susceptibility levels.

\section{Results}

\section{Collapse dolines inventory map}

In this paper, a collapse dolines inventory map is realized regardless of other doline types (Fig. 11). Collapse dolines phenomena occurred mainly in South of Safi, along of the SW-NE lineament direction.

The adopted approaches for building this inventory map allowed us to have a representative distribution of phenomena. The inventory includes a total of 20 collapse dolines completely identified and mapped (cf. Fig. 11). The collapse dolines were found to affect $0.041 \%$ of the total study area (Table 1). Continental quaternary formation (Qc2) is the most affected by collapse doline events, comprising $60 \%$ of the inventoried collapse dolines, followed by Plio-Quaternary Formation (PQ) at $30 \%$ and Evaporitic Complex Formation (Js) at $10 \%$ (Table 2).

\section{Collapse dolines susceptibility map}

A collapse dolines susceptibility map has been built on the basis of the GIS matrix method, (Fig. 12). The susceptibility values varied between 0 and 100 in each combination of classes of predisposing factors. The values obtained were visualized by means of 5 susceptibility levels (very low, low, moderate, high and very high) (Table 3 ) found in other works using the natural-breaks method. (Irigaray 1995; Irigaray et al. 2007; El Hamdouni 2001; Fernández et al. 2003, 2008; Jiménez-Perálvarez et al. 2009).

The very high and high susceptibility levels represent less than $1 \%$ of the surface area studied, but this percentage is concentrated in the relatively reduced area, mainly in the South and the South East of Safi city. 


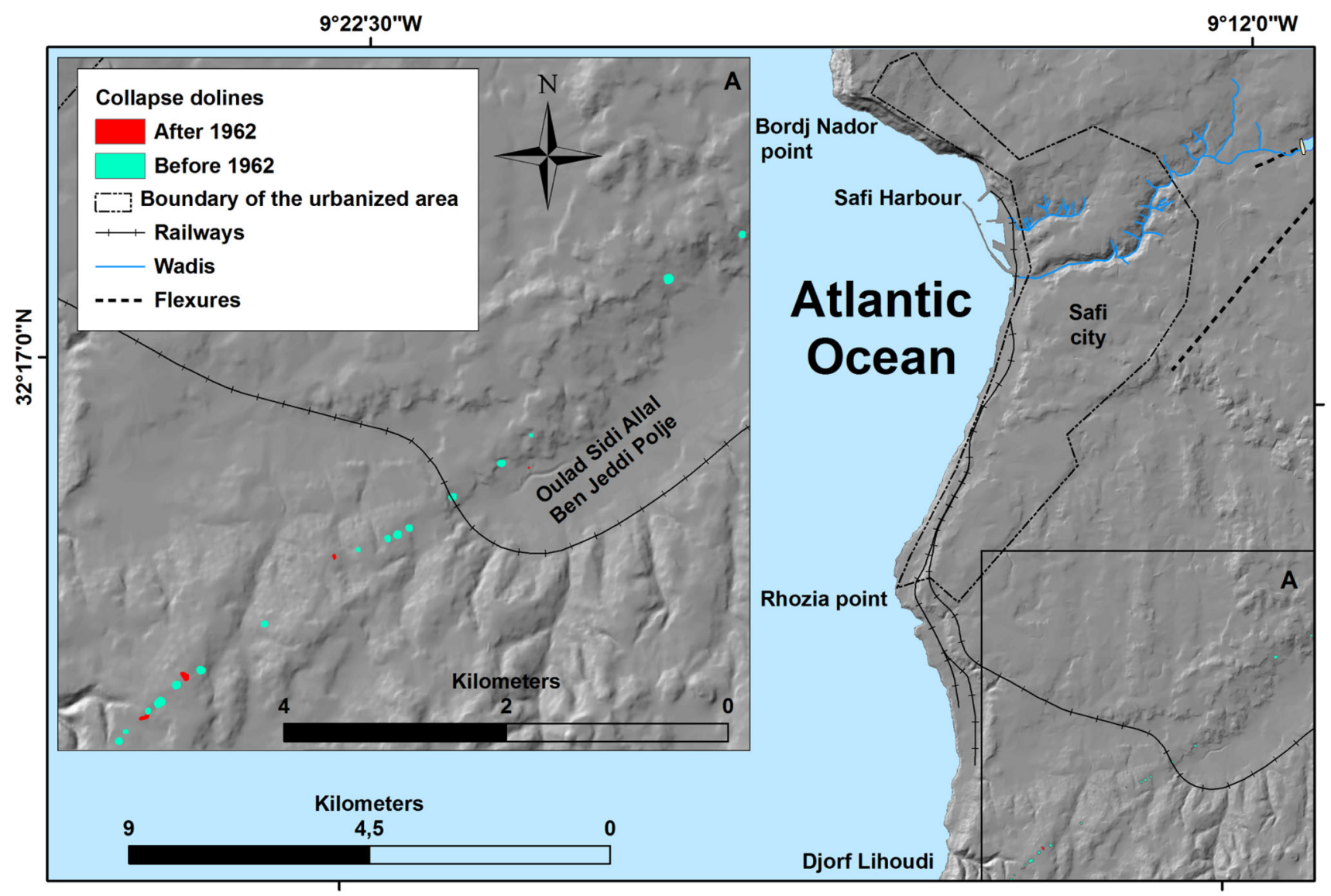

Fig. 11 Collapse dolines inventory map $(A)$ enlargement of South of the study area

Table 1 Collapse dolines inventory and dimensions (study area $=107,864,303.159 \mathrm{~m}^{2}$ )

\begin{tabular}{|c|c|c|c|c|c|c|c|c|c|c|c|c|}
\hline \multicolumn{7}{|l|}{ Affected area $\left(\mathrm{m}^{2}\right)$} & \multicolumn{3}{|c|}{ Length $(\mathrm{m})$} & \multicolumn{3}{|c|}{ Depth (m) } \\
\hline Collapse dolines & $\mathrm{n}$ & Ama & Ami & Ame & Ato & $\%$ Relate to total area & Lma & Lmi & Lme & Dma & Dmi & Dme \\
\hline Total & 20 & 5692 & 30 & 2236 & 44.712 & 0.041 & 97 & 5 & 53.5 & 40 & 1 & 9.85 \\
\hline
\end{tabular}

Ama maximum area, Ami minimum area, Ame mean area, Ato total area, Lma maximum length or diameter, Lmi minimum length or diameter, Lme mean length or diameter, Dma maximum depth, Dmi minimum depth, Dme mean depth

Table 2 Collapse dolines inventory, percentages in each lithology
$\%$ of collapse dolines inventoried in each lithology relate to total lithologies of each typology

\begin{tabular}{lllllllllll}
\hline Typology & Js & Ci1 & Ci2a & Ci2b & PQ & Qc1 & Qc2 & Qm1 & Qm2 & Total \\
\hline Collapse dolines & 10.00 & 0.00 & 0.00 & 0.00 & 30.00 & 0.00 & 60.00 & 0.00 & 0.00 & 100.00
\end{tabular}

Js Upper Jurassic Limestone-Evaporitic Complex formation, Ci1 Limestone-Lower Limestone formation, Ci2 Brown Clay formation, Ci2b Dridrat Limestone formation, $P Q$ bioclastic limestone-Plio-Quaternary formations, $Q c 1$ middle continental quaternary formation, $Q c 2$ bioclastic limestone-recent continental quaternary formation, $Q m 1$ middle marine quaternary formation, $Q m 2$ recent marine quaternary formation

\section{Collapse dolines susceptibility validations}

The attained results (Fig. 13a) show a better degree of fit for the validation which was made with the same inventory (before 1962) used to build the collapse dolines susceptibility map (cf. Fig. 12); the degree of fit for the very low and low susceptibility classes is $3.41 \%$ and for the high and very high susceptibility classes is more than $80 \%$. But, the (Fig. 13b) shows a lesser degree of fit for the validation which was made with the collapse doline 


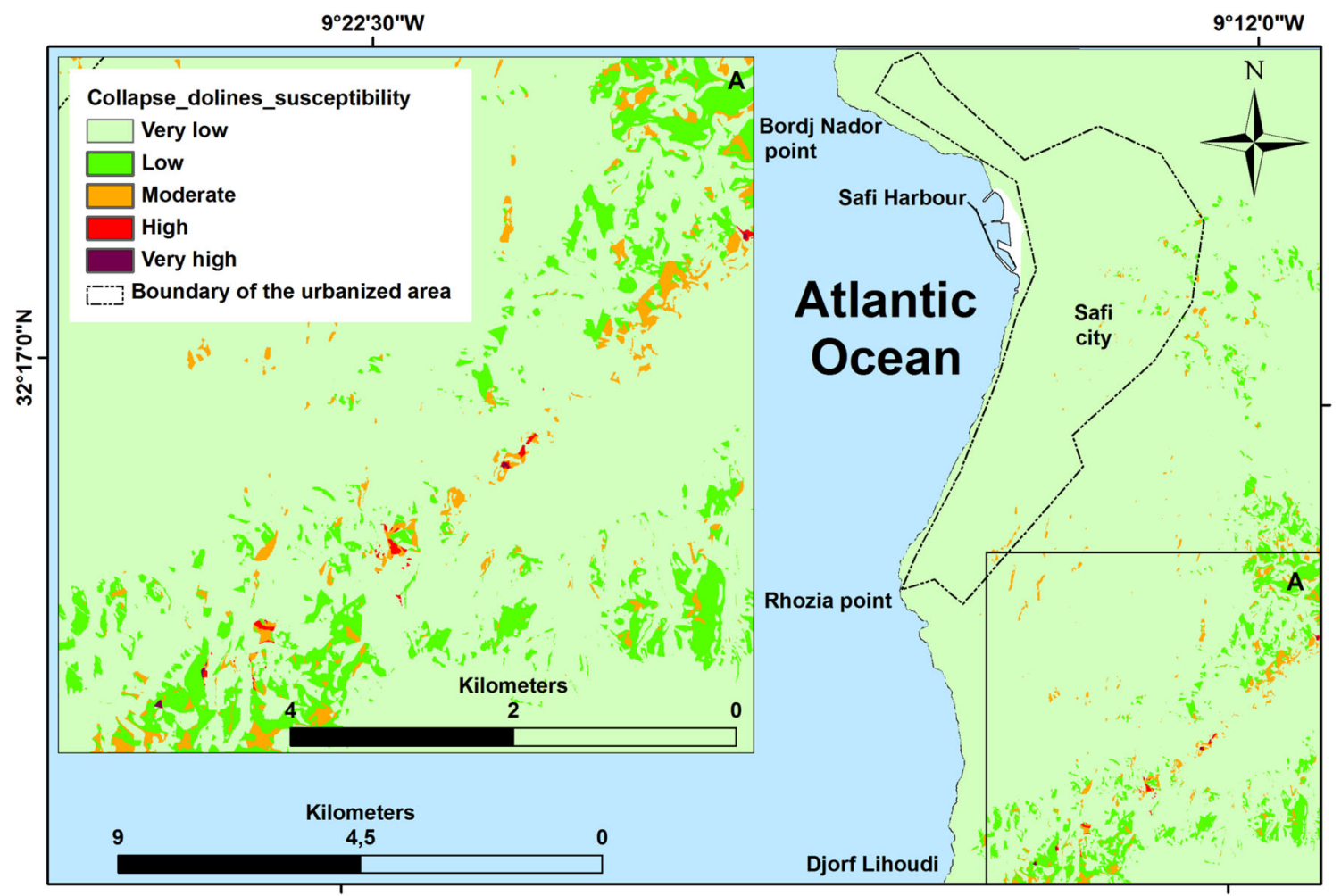

Fig. 12 Collapse dolines susceptibility map with enlargement of South of the study area $(A)$

Table 3 Collapse dolines susceptibility (the values show the surface of the study area and the percentages of each level of susceptibility compared to the entire study area)

\begin{tabular}{lcr}
\hline Collapse dolines susceptibility & \multicolumn{2}{l}{ Before 1962} \\
\cline { 2 - 3 } The susceptibility & $\%$ & $\mathrm{Km}^{2}$ \\
\hline Very low & 58.92 & 63.25 \\
Low & 26.90 & 28.88 \\
Moderate & 10.28 & 11.03 \\
High & 3.12 & 3.36 \\
Very high & 0.77 & 0.82 \\
Total & 99.99 & 107.34 \\
\hline
\end{tabular}

inventory (after 1962); the degree of fit for the very low class attains 100 and $0 \%$ for the rest of classes.

\section{Discussion}

\section{Collapse dolines inventory map}

The inventory map shows that collapse dolines phenomena are strictly localized in the South of Safi city. The collapse doline events are rare; sixteen events occurred before 1962 and just four collapse dolines occurred after 1962. This localization is related to the causal factors, such as lithological factor (the presence of the deep karst: the Upper Jurassic Limestone-Evaporitic Complex Formation, and the superficial karst: the Plio-Quaternary formations and the continental quaternary formations). in the south of the study area, the Evaporitic Complex Formation (rich in gypsum and anhydrite) outcrops and influences on the overlying karst which explain the number of collapse dolines occurring in this area; $90 \%$ collapse events affect the superficial karst and just $10 \%$ affect the deep karst, however this percent masks the fact that the deep karst is the origin of superficial karst collapses (cf. Table 2).

The collapse dolines distribution follows the SW-NE direction which is the same direction of the tectonic structures such as flexures and faults observed in the study area (cf. Fig. 11). One might suggest the presence of such tectonic structures guiding the distribution of these dolines and which would be parallel to the faults and flexures located further North. Speleological exploration of collapse dolines corroborates this hypothesis. Indeed, many of collapse dolines show tectonic deformations such as anticlinal folds, reverse faults and microfolds. Geophysical studies of seismic and electrical order must be scheduled later to confirm their presence.

Two of the twenty collapse dolines have been dated precisely; respectively in 1968 and 1996. These dates 
Fig. 13 a Collapse dolines susceptibility map validation (true validation). b Collapse dolines susceptibility map validation
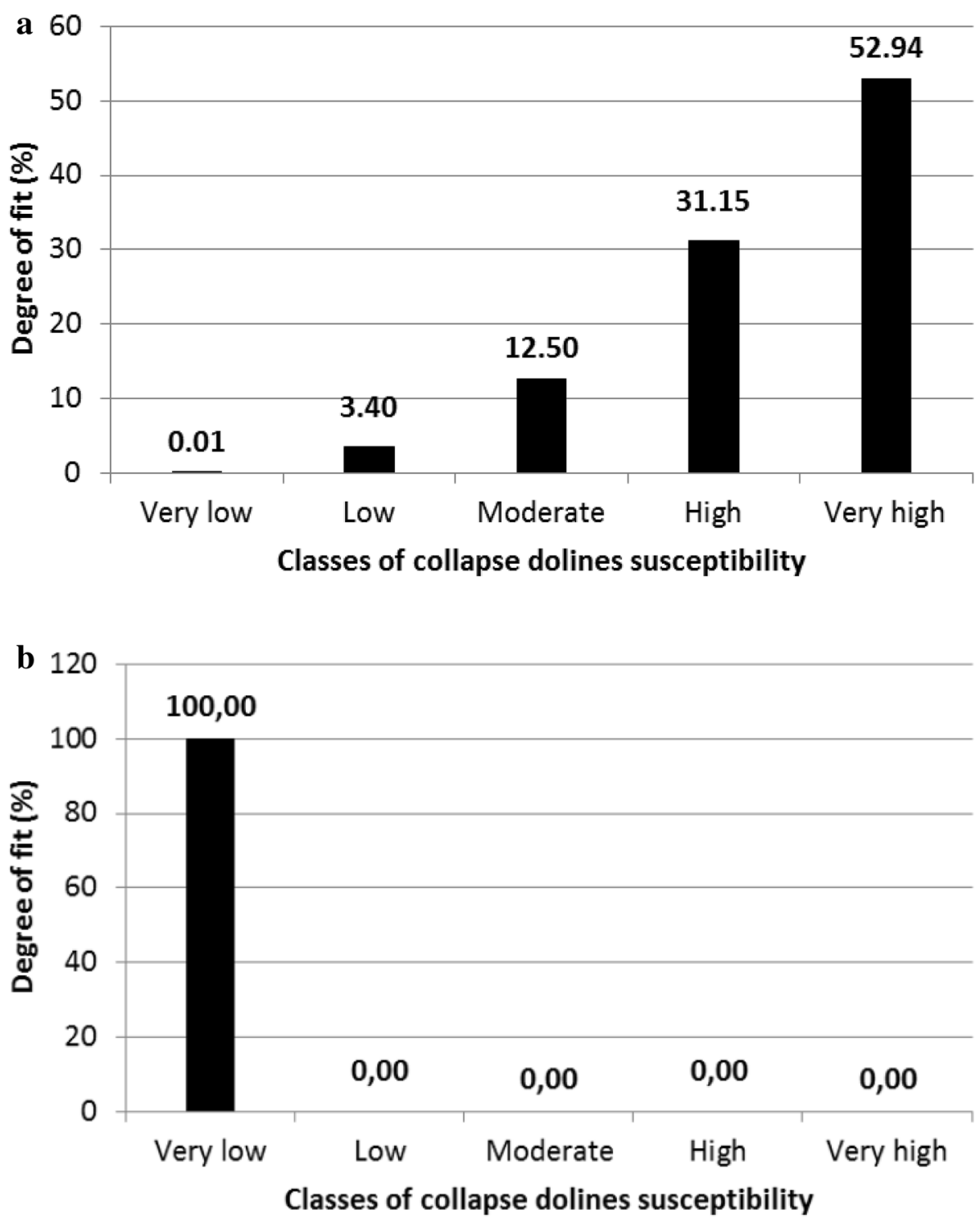

correspond to years of intense rainfall in the region (the annual rainfall in Safi reached 517 and $1019 \mathrm{~mm}$, in 1968 and 1996, respectively, compared to the annual average of $350 \mathrm{~mm}$ ). The others collapse dolines have no specific dates, and a dating test of one of them to give an age dating back more than 5000 years (Weisrock and Lunski 1987). The old age of collapse dolines is attested by their shapes. In fact, some collapse dolines have steep walls, but most others were eroded and filled with sediment and blocks, and consequently their walls become less steep. For this reason, the produced inventory map can be classified among the geomorphological historical inventory (Guzzetti et al. 2012). This collapse dolines inventory map is an essential step to build the collapse dolines susceptibility map.

\section{Collapse dolines susceptibility maps and validations}

In this research, one collapse dolines susceptibility map was produced by the GMM method. This map (cf. Fig. 12) shows that the high and very high susceptibility levels are spatially concentrated in the South of the study area, which is favorable to collapsing, following a SW-NE alignment.

This susceptibility reflect the predisposing factors in this part of interest area such as the presence of the karst formations of the Upper Jurassic and Plio-Quaternary Formation which is formed by the gypsum and the bioclastic limestone, respectively. In addition, the topographic factors such as slope and aspect play a key role; through the great polje called "Oulad Sidi Allal Ben Jeddi" (cf. Fig. 11). This polje is a large karst depression which has a $7 \mathrm{~km}$ 


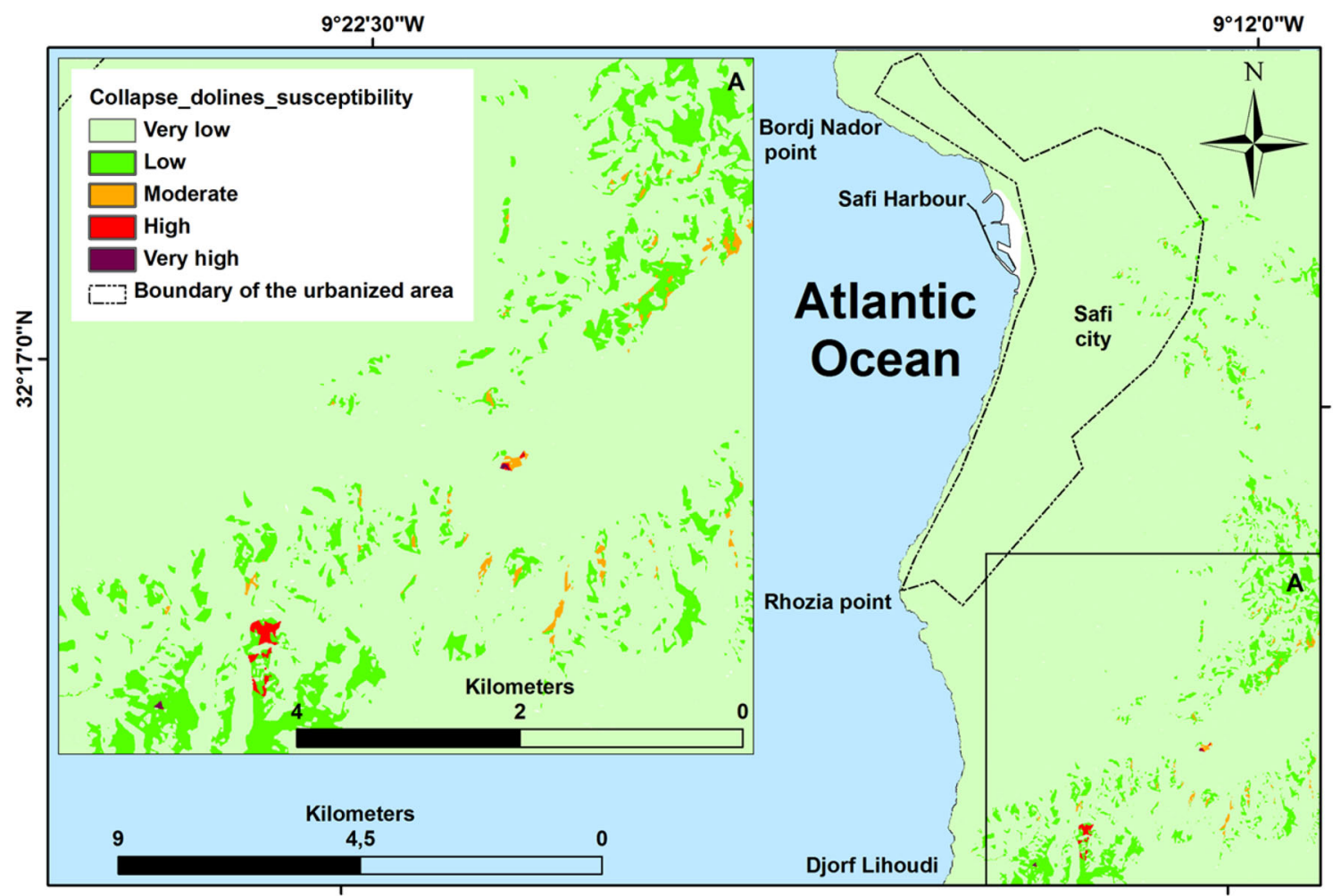

Fig. 14 The final collapse dolines susceptibility map with an enlargement of south of the study area $(A)$

length and has a NE-SW direction, receives rainwater and becomes a large lake, and then the water is drained through sinks or ponors towards the Atlantic Ocean near the Jorf Lihoudi cliff.

The quality of this map is tested by the degree of fit method. On the one hand, the obtained results (cf. Fig. 13a) show a lower relative error in the very low and low susceptibility classes that reaches $3.41 \%$ and also show a higher relative accuracy reaching more than $80 \%$. This validation type, where the same inventory is used, is called "True validation". Some authors rely on this type of validation to test their suggested models. In contrast, other authors insist that the validation must be made by an independent and different inventory (Irigaray et al. 1999; Chung and Fabbri 2003; Remondo et al. 2003; Galve et al. 2008).

On the other hand, the obtained results (cf. Fig 13b) show a bad degree of fit for this collapse dolines susceptibility map. The degree of fit for the very low susceptibility class is $100 \%$, and $0 \%$ for the rest of classes in this collapse dolines susceptibility map validation; this error is unacceptable because it exceeds the $10 \%$ threshold accepted by other works (Irigaray et al. 2007). This error is probably due to the use of an inventory not accessing four events (collapse doline after 1962). Additional errors, though very minor, are due to differences in scale of the aerial photographs. Consequently, the low number of collapse dolines events had a negative impact on the quality of this susceptibility map.

For this reason, a second map was produced with the same GMM method. Firstly, the twenty events of collapse dolines were randomly split into two equal groups. This operation is conducted by using the Hawth's Analysis Tools (Version 3.27) as an Arc GIS extension. Secondly, the first group was used to build the new susceptibility map (Fig. 14), and finally the second group was used to validate this map by the degree of fit method (Fig. 15a, b).

The new collapse dolines susceptibility map shows that the high and very high susceptibility levels are spatially located in the South of study area, but they are more limited. The moderate susceptibility level is not pronounced compared to the first map where this level is clear and therefore the alignment is well represented.

Regarding the susceptibility map validation results, the true validation has given a good result with $100 \%$ for the high and very high susceptibility classes (cf. Fig. 15a). The second validation, where a different inventory was used, also shows a good degree of fit; with nearly $60 \%$ for the high and very high susceptibility levels, $40 \%$ for the moderate level and $0 \%$ for the low and very low susceptibility levels (cf. Fig. 15b). On the basis of these results, this second map displays the collapse dolines susceptibility levels in a manner of more reliable and more adequate. 
Fig. 15 a Collapse dolines susceptibility map validation (true validation). b Collapse dolines susceptibility map validation
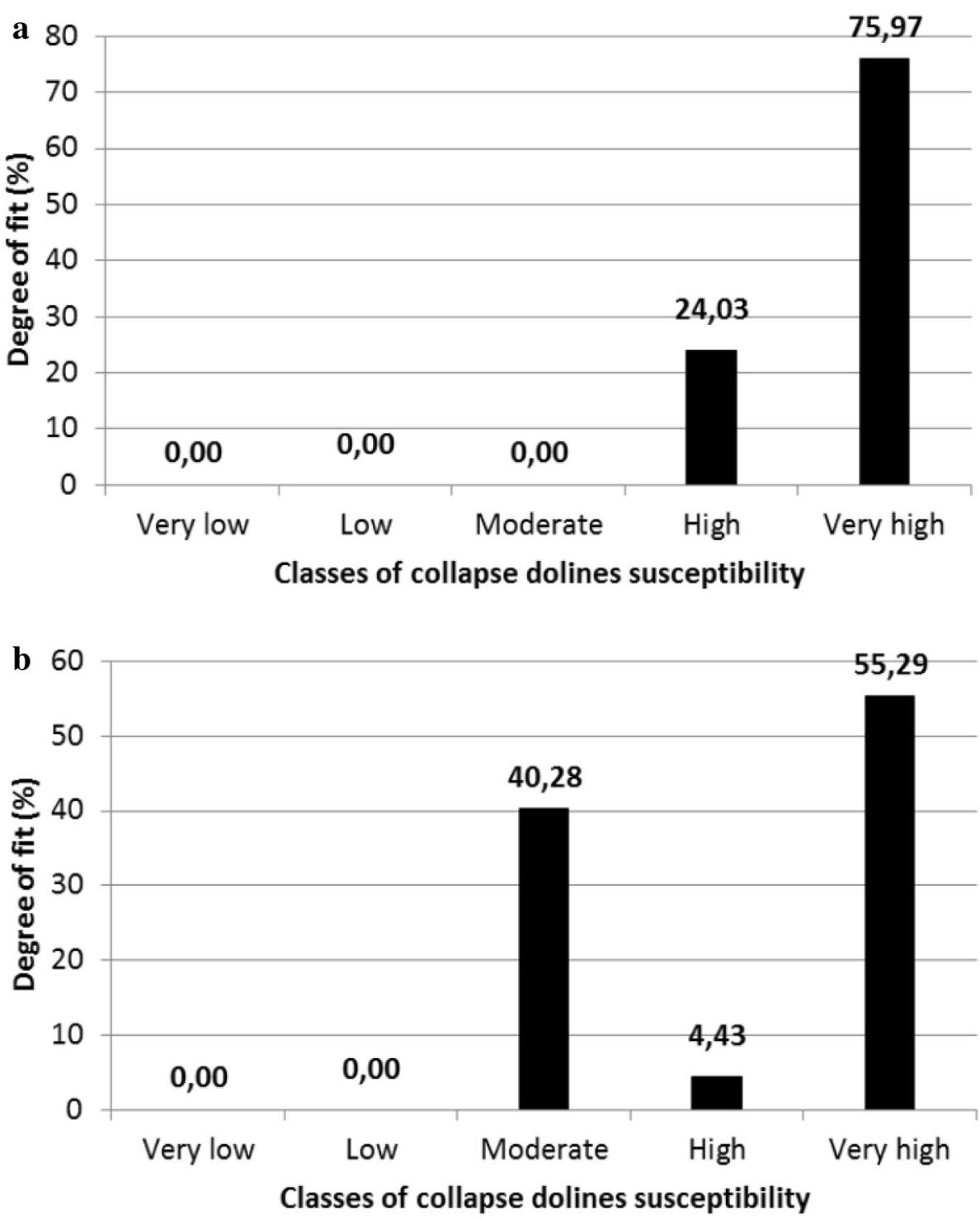

Therefore, this map is more accurate compared to the first map.

\section{Conclusions}

In this work, the collapse dolines inventory map was produced using conventional methods: geomorphological field mapping and visual interpretation of aerial photographs (Guzzetti et al. 2012). This collapse dolines inventory map was produced according to the international classification of dolines (Ford and Williams 1989).

The quality of a collapse dolines inventory depends on its accuracy, and on the type and certainty of the information shown in the map (Galli et al. 2008; Guzzetti et al. 2012). Regarding the quality of the inventory map, the size of the smallest collapse dolines portrayed in our map is equal to $30 \mathrm{~m}^{2}$ (Harp and Jibson 1995; Malamud et al. 2004; Guzzetti et al. 2012); the produced inventory was considered nearly complete.

This collapse dolines inventory map shows that only $0.041 \%$ of the surface of the study area is affected by collapse dolines, it should be noted that this area is well known for its high level of industrial activity, the presence of railways, and it will contain the new harbor of Safi and the thermal power station near Djorf Lihoudi.

Moreover, the collapse dolines inventory map was used with four environmental factors (lithology, DEM, slope angle and slope aspect) to build the collapse dolines susceptibility map. This collapse dolines susceptibility map show that the very high and high susceptibility levels represent less than $1 \%$ of the surface area studied, but this percentage is limited to the relatively reduced area, mainly in the South of the city of Safi. Nevertheless, this smallest 
part of the study area is very important for the economic and logistic activities.

Due to the lack of structural and hydrogeological data (structural maps and piezometric maps), just four predisposing factors (lithology, DEM, slope angle and slope aspect) were used to build the collapse dolines susceptibility map. This collapse dolines susceptibility map shows that the very high and high susceptibility levels represent less than $1 \%$ of the surface area studied, but this percentage is limited to the relatively reduced area, mainly in the South of the city of Safi along a South West-North East direction. Nevertheless, this smallest part of the study area is very important for the economic and logistic activities. The urbanized area of the city of Safi is spared of the collapse risks. It generally shows a very low collapse dolines susceptibility.

However, the applications of GMM method, already used in other works studying landslides, give satisfactory and acceptable results. In fact, the quality of the collapse dolines susceptibility map was tested by the degree of fit method and the obtained results show a good degree of fit for collapse dolines susceptibility map, especially when the number of events is important.

Finally, the obtained collapse dolines susceptibility map in this paper is a primordial phase for future hazard and risk assessment in the study area in the future.

Acknowledgments The authors wish to thank Mr. Mohamed BELKAID and Mr. Boubker BELKAID for their devotion and availability, and thank also the English teachers of Al Hidaya Islamia school of Safi: Mrs. Abdelhak Mahfoudi, Omar Fadouchi, Abdellah Mansar and Radouane Belkhadir for their spelling corrections. Thanks also to Mr. Mamoune Amrani Marrakchi and Miss. Imane Amine of the Moroccan Association of Speleology (AMS) in Casablanca for their guidance in the exploration of some dolines, as well as members of the Ocean Association of Speleology (AOS) in Safi.

\section{References}

Aboumaria K (1993) Les formations quaternaires du Sahel des Doukkala (Meseta occidentale marocaine): mise en place et évolution post-sédimentaire. In: Ouadia M (1998) Les formations plio-quaternaires dans le domaine mesetien occidental du Maroc entre Casablanca et Safi : géomorphologie, sédimentologie, paléoenvironnements quaternaires et évolution actuelle. Thèse de Doctorat d'Etat Ès Sciences, Université Mohamed V, $\mathrm{N}^{\circ}$ 1646, Rabat, p 321

Beck BF, Sinclair WC (1986) Sinkholes in Florida: an introduction. Florida Sinkhole Research Institute Report 85-86-4

Brunsden D (1985) Landslide types, mechanisms, recognition, identification. In: Morgan CS (ed) Landslides in the South Wales coalfield, proceedings symposium. The Polytechnic of Wales, pp 19-28

Carrara A, Cardinali M, Guzzetti F, Reichenbach P (1995) GIS technology in mapping landslide hazard. In: Carrara A, Guzzetti $\mathrm{F}$ (eds) Geographical information systems in assessing natural hazards. Kluwer Academic Publisher, Dordrecht, pp 135-175
Carruesco C (1989) Genèse et évolution de trois lagunes du littorale atlantique depuis l'Holocène: Oualidia, Moulay Bou Salham (Maroc) et Arcachon (France). Thèse de Doctorat Ès Sciences. Bordeaux I, vol 2, p 442

Choubert G (1956, réimpression 1978) Carte géologique du Maroc1/500 000: El Jadida.- 1 carte géol. coul.; feuille 1. Notes et Mémoires du Service Géologique du Maroc, $\mathrm{N}^{\circ} 70$

Choubert G (1957, réimpression 1978) Carte géologique du Maroc1/500 000: Marrakech.-1 carte géol. coul.; feuille 2. Notes et Mémoires du Service Géologique du Maroc, $N^{\circ} 70$

Chung CF, Fabbri AG (2003) Validation of spatial prediction models for landslide hazard mapping. Nat Hazards 30:451-472. doi:10. 1023/B:NHAZ.0000007172.62651.2b

Clerici A, Perego S, Tellini C, Vescovi P (2002) A procedure for landslide susceptibility zonation by the conditional analysis method. Geomorphology 48:349-364. doi:10.1016/S0169-555X(02)00079-X

Cross M (1998) Landslide susceptibility mapping using the matrix assessment approach: a Derbyshire case study. In: Maund JG, Eddlestonb M (eds) Geohazards in engineering geology. The geological society, vol 15. Engineering Geology Special Publications, London, pp 247-261

Dai J, Lei M, Liu W, Tang S, Lai S (2008) An assessment of karst collapse hazards in Guilin, Guangxi Province, China. In: Yuhr LB, Alexander EC Jr, Beck BF (eds) Sinkholes and the engineering and environmental impacts of karst. Proceedings of the 11th Multidisciplinary Conference on Sinkholes and the Engineering and Environmental Impacts of Karst, vol. 183. ASCE Geotechnical Special Publication, Tallahassee, pp 156-164

DeGraff JV, Romesburg HC (1980) Regional landslide-susceptibility assessment for wildland management: a matrix approach. In: Coates DR, Vitek JD (eds) Thresholds in geomorphology, vol 19. Alien \& Unwin, Boston, pp 401-414

Edmonds CN (2001) Predicting natural cavities in chalk. Spec Publ Geol Soc Lond 18:29-38

El Gharbaoui A (1987) Les formes et les formations karstiques, La grande Encyclopédie du Maroc, vol 3, Gremona, pp 126-129

El Hamdouni R (2001) Estudio de Movimientos de Ladera en la Cuenca del Río Ízbor mediante un SIG: Contribución al Conocimiento de la Relación entre Tectónica Activa e Inestabilidad de Vertientes. Unpublished PhD Thesis, Department of Civil Engineering, University of Granada, Spain

Fernández T, Irigaray C, El Hamdouni R, Chacón J (2003) Methodology for landslide susceptibility mapping by means of a GIS. Application to the Contraviesa area (Granada, Spain). Nat Hazards 30:297-308. doi:10.1023/B:NHAZ.0000007092.51910.3f

Fernández T, Irigaray C, El Hamdouni R, Chacón J (2008) Correlation between natural slope angle and rock mass strength rating in the Betic Cordillera, Granada, Spain. Bull Eng Geol Environ 67:153-164. doi:10.1007/s10064-007-0118-x

Ferré M, Ruhard JP (1975) Ressources en eau du Maroc, tome 2: Plaines et bassins du Maroc atlantique, Editions du Service Géologique du Maroc n²31, Rabat, p 454

Field MS (2002) A lexicon of cave and karst terminology with special reference to environmental karst hydrology. Report EPA/600/R02/003. United States Environmental Protection Agency, Washington, DC, p 214

Ford DC, Williams PW (1989) Karst geomorphology and hydrology. Unwin Hyman, London and Boston

Galli M, Ardizzone F, Cardinali M, Guzzetti F, Reichenbach P (2008) Comparing landslide inventory maps. Geomorphology 94:268-289. doi:10.1016/j.geomorph.2006.09.023

Galve JP, Bonachea J, Remondo J, Gutierrez F, Guerrero J, Lucha P, Cendrero A, Gutierrez M, Sanchez JA (2008) Development and validation of sinkhole susceptibility models in mantled karst settings. A case study from the Ebro valley evaporite karst (NE Spain). Eng Geol 99(3-4):185-197 
Galve JP, Gutiérrez F, Remondo J, Bonachea J, Lucha P, Cendrero A (2009) Evaluating and comparing methods of sinkhole susceptibility mapping in the Ebro Valley evaporite karst (NE Spain). Geomorphology 111(3-4):160-172

Gao Y, Alexander Jr EC (2003) A mathematical model for a sinkhole probability map in Fillmore County, Minnesota. In: Beck BF (ed), Sinkholes and the Engineering and Environmental Impacts of Karsts. Proceedings of the 9th Multidisciplinary Conference, Huntsville, Alabama, 6-10 September: ASCE Geotechnical Special Publication, 122, pp 439-449

Gigout M (1951) Etudes géologiques sur la Méséta marocaine occidentale (Arrière-pays de Casablanca, Mazagan et Safi). Travaux de l'Institut Scientifique Chérifien $\mathrm{N}^{\circ} 3$, et Notes et Mémoires du Service Géologique. $N^{\circ}$ 86. Rabat, Imprimerie Maroc-Matin, 2 tomes, p 507

Gigout M (1954a) Carte géologique de la Méséta entre Settat et Mazagan (El Jadida) (Doukkala et Chaouia occidentale, feuille Settat et Oualidia) au 1/200.000, Notes et Mémoires du Service Géologique du Maroc, $\mathrm{N}^{\circ} 75$

Gigout M (1954b) Carte géologique de la Méséta entre Mechrâ Benâbbou et Safi (Abda, Doukkala et massif des Rhamna) au 1/200.000, Notes et Mémoires du Service Géologique du Maroc, $\mathrm{N}^{\circ} 84$

Gilli É (2011) Karstologie: Karsts, grottes et sources. Dunod édit, Paris, p 248

Goodchild MF (1986) Spatial autocorrelation, CATMOG 47. Geo Books, Norwich

Goodings DJ, Abdulla WA (2002) Stability charts for predicting sinkholes in weakly cemented sand over karst limestone. Eng Geol 65:179-184

Gutiérrez-Santolalla F, Gutiérrez-Elorza M, Marín C, Maldonado C, Younger PL (2005) Subsidence hazard avoidance based on geomorphological mapping. The case study of the Ebro River valley mantled karst (NE Spain). Environ Geol 48:370-383

Guzzetti F, Carrara A, Cardinali M, Reichenbach P (1999) Landslide hazard evaluation: a review of current techniques and their application in a multi-scale study, Central Italy. Geomorphology $31: 181-216$

Guzzetti F, Cardinali M, Reichenbach P, Carrara A (2000) Comparing landslide maps: a case study in the upper Tiber River Basin, Central Italy. Environ Manag 25(3):247-363

Guzzetti F, Reichenbach P, Ardizzone F, Cardinali M, Galli M (2006) Estimating the quality of landslide susceptibility models. Geomorphology 81:166-184

Guzzetti F, Mondini A, Cardinali M, Fiorucci F, Santangelo M, Chang KT (2012) Landslide inventory maps: new tools for an old problem. Earth Sci Rev 112:42-66

Harp EL, Jibson RL (1995) Inventory of landslides triggered by the 1994 Northridge, California earthquake. US Geological Survey Open File Report, pp 95-213

Hazan R, Monition L (1963) Etat des connaissances sur l'hydrogéologie karstique au Maroc. in: Congr. Berkeley (Calif.), 1963, Eaux souterr., Ass. int. Hydrol. sci., publ. n64, Gentbrugge, pp 455-472

Irigaray C (1995) Movimientos de Ladera: Inventario, Análisis y Cartografía de la Susceptibilidad Mediante un Sistema de Información Geográfica. Aplicación a las Zonas de Colmenar (Málaga), Rute (Córdoba) y Montefrío (Granada). Unpublished $\mathrm{PhD}$ Thesis, Department of Civil Engineering, University of Granada, Spain

Irigaray C, Fernández T, El Hamdouni R, Chacón J (1999) Verification of landslide susceptibility mapping. A case study. Earth Surf Process Landf 24:537-544

Irigaray C, Fernández T, El Hamdouni R, Chacón J (2007) Evaluation and validation of landslide-susceptibility maps obtained by a GIS matrix method: examples from the Betic Cordillera (southern Spain). Nat Hazards 41:61-79

Jennings JN (1985) Karst geomorphology. Blackwell, Oxford
Jiménez-Perálvarez JD, Irigaray C, El Hamdouni R, Chacón J (2009) Building models for automatic landslide-susceptibility analysis, mapping and validation in ArcGIS. Nat Hazards 50:571-590. doi:10.1007/s11069-008-9305-8

Kaufmann O, Quinif Y (2002) Geohazard map of cover-collapse sinkholes in the Tournaisis area, southern Belgium. Eng Geol 65:117-124

Lamelas MT, Marinoni O, Hoppe A, de la Riva J (2008) Doline probability map using logistic regression and GIS technology in the central Ebro Basin (Spain). Environ Geol 54:963-977

Maharaj RJ (1993) Landslide processes and landslide susceptibility analysis from an upland watershed a case study from St. Andrew, Jamaica, West Indies. Eng Geol 34:53-79

Malamud BD, Turcotte DL, Guzzetti F, Reichenbach P (2004) Landslide inventories and their statistical properties. Earth Surf Proc Land 29(6):687-711

Mazéas JP (1967) Carte géotechnique de Safi au 1/20000, Notes et Mémoires du Service Géologique du Maroc, $N^{\circ} 189$

Nachbaur A, Rohmer J (2011) Managing expert-information uncertainties for assessing collapse susceptibility of abandoned underground structures. Eng Geol 123:166-178

Nicod J (1976) Karsts des gypses et des évaporites associées, In: Annales de Géographie, t. 85, $\mathrm{n}^{\circ}$ 471. pp 513-554

Oh HJ, Lee S (2010) Assessment of ground subsidence using GIS and the weights-of-evidence model. Eng Geol 115:36-48

Ouadia M (1998) Les formations plio-quaternaires dans le domaine mesetien occidental du Maroc entre Casablanca et Safi: géomorphologie, sédimentologie, paléoenvironnements quaternaires et évolution actuelle. Thèse de Doctorat d'Etat Ès Sciences, Université Mohamed V, N 1646, Rabat, p 321

Papadopoulou-Vrynioti Kyriaki, Bathrellos George D, Skilodimou Hariklia D, Kaviris George, Makropoulos Kostas (2013) Karst collapse susceptibility mapping considering peak ground acceleration in a rapidly growing urban area. Eng Geol. doi:10.1016/j. enggeo.2013.02.009

Remondo J, González A, Díaz de Terán JR, Cendrero A, Fabbri A, Cheng CF (2003) Validation of landslide susceptibility maps: examples and applications from a case study in Northern Spain. Nat Hazards 30:437-449

Reuter HI, Nelson A (2009) Geomorphometry in ESRI packages, in geomorphometry concepts, software, applications. In: Hengl T, Reuter HI (eds) Developments in soil science, vol 33. Elsevier, Amsterdam. Linacre House, Oxford, p 775

Roch E (1930) Carte géologique provisoire des Abda et des Djebilet occidentales, au 1/200000. Notes et mémoires du Service Mines et Carte géologique. Maroc, $\mathrm{n}^{\circ} 10$

Roch E (1950) Histoire stratigraphique du Maroc. Notes et mémoires du Service Géologique $n^{\circ} 80$. Les Frères DOULADOURE. Toulouse, p 435

Theilen-Willige B, Ait Malek H, Charif A, El Bchari F, Chaïbi M (2014) Remote sensing and GIS contribution to the investigation of karst landscapes in NW-Morocco. Geosciences 4:50-72. doi: 10.3390/geosciences 4020050

Waltham AC, Fookes PG (2003) Engineering classification of karst ground conditions. Q J Eng GeolHydrogeol 36:101-118

Weisrock A, Lunski S (1987) Le karst pliocène de la région de Safi (Maroc atlantique). Karstologia 9:31-36

White WB (1988) Geomorphology and hydrology of karst terrains. Oxford University Press, Oxford and New York

Williams PW (2003) Dolines. In: Gunn J (ed) Encyclopedia of caves and karst science. Taylor \& Francis e-Library, New York, pp 628-642

Williams PW (2006) Doline. In: Goudie AS (ed) Encyclopedia of geomorphology. Routledge, London

Yilmaz I (2007) GIS based susceptibility mapping of karst depression in gypsum: a case study from Sivas basin (Turkey). Eng Geol 90:89-103 